Journal of Telenursing (JOTING)

Volume 1, Nomor 2, Desember 2019

e-ISSN: 2684-8988

p-ISSN: 2684-8996

DOI: https://doi.org/10.31539/joting.v1i2.912

\title{
PENGALAMAN ORANG DENGAN HIV AIDS PENGGUNA NAPZA SUNTIK SELAMA MENJALANI TERAPI ANTIRETROVIRAL DAN METADON
}

\author{
Idramsyah $^{1}$, Agung Waluyo ${ }^{2}$, I Made Kariasa ${ }^{3}$ \\ Politeknik Kesehatan Kementerian Kesehatan Bengkulu ${ }^{1}$ \\ Universitas Indonesia ${ }^{2,3}$ \\ idram_81@yahoo.com ${ }^{1}$
}

\begin{abstract}
ABSTRAK
Tujuan penelitian ini yaitu untuk mempelajari pengalaman Orang Dengan HIV AIDS (ODHA) Pengguna Jarum Suntik (Penasun) selama menjalani terapi anti-retroviral (ARV) dan Metadon. Metode penelitian kualitatif ini menggunakan pendekatan fenomenologi. Hasil analisis menunjukkan bahwa ODHA Penasun merasakan hidup normal secara fisik dan memiliki kehidupan psikososial yang positif. Partisipan mengalami perasaan jenuh dengan rutinitas dan kewajiban serta sering dihinggapi perasaan takut. ODHA Penasun juga mengalami efek samping terapi ARV dan Metadon bersamaan. Simpulan, Meskipun ODHA Penasun merasakan manfaat terapi, namun tetap mengalami berbagai masalah fisik dan psikososial akibat prosedur pengobatan dan respon pengobatan ARV dan Metadon.
\end{abstract}

Kata Kunci: Antiretroviral, HIV/AIDS, Metadon, ODHA Penasun

\begin{abstract}
The aim of this research is to study the experience of People With HIV AIDS (PLWHA) Injection Drugs Users (IDUs) while undergoing anti-retroviral (ARV) and Methadone therapy. This qualitative research method uses a phenomenological approach. The interview transcript was analyzed by the Colaizi analysis stage. The analysis showed that ODHA of IDU felt physically normal and had a positive psychosocial life. Participants experience feelings of saturation with routine and obligation and are often seized with feelings of fear. PLWHA IDUs also experience side effects of concomitant $A R V$ and Methadone therapy. Conclusion, Although PLWHA IDUs felt the benefits of therapy, they still experience various physical and psychosocial problems due to treatment procedures and ARV and Methadone treatment response.
\end{abstract}

Keywords: Antiretroviral, HIV / AIDS, IDUs, Methadone, ODHA 


\section{PENDAHULUAN}

Injecting Drug Users (IDU) Living With HIV AIDS (ILWHA) merupakan pengguna Narkotika Psikotropika dan Zat Adiktif (Napza) suntik yang mengidap HIV AIDS atau dikenal dengan istilah ODHA Penasun. ODHA Penasun telah tersebar di 120 negara. UNAIDS dalam the GAP report 2014 melaporkan jumlah penasun mencapai 12,7 juta jiwa di dunia, dan 1,7 juta (13\%) merupakan ODHA. Bahkan diperkirakan sebanyak (30\%) penderita baru HIV di Sub-Sahara Afrika merupakan Penasun (UNAIDS, 2014). Studi empiris menyimpulkan ada hubungan antara pola penyalahgunaan heroin dengan kejadian infeksi HIV (Strathdee et al., 2010). Jika heroin telah mencapai suatu negara maka akan terjadi peningkatan transmisi HIV di negara tersebut, termasuk Indonesia.

Indonesia merupakan negara dengan prevalensi orang dengan HIV AIDS (ODHA) Pengguna Napza suntik (Penasun) tertinggi pertama di dunia yaitu mencapai lebih dari 30.000 atau 20-39,9\%, diikuti Pakistan, Thailand, Ukraina dan Malaysia (UNAIDS, 2014). Secara kumulatif sejak 1987-2014, jumlah ODHA Penasun telah mencapai $15,2 \%$. Namun selama 5 tahun terakhir terlihat fluktuasi dengan kecenderungan menurun, yaitu tahun 2011 ada 3.299 ODHA Penasun, tahun 2014 ada 1,348 ODHA Penasun (Kemenkes RI, 2014).

ODHA Penasun yang memenuhi kriteria terapi harus menjalani terapi antiretroviral (ARV) dan terapi metadon. Terapi antiretroviral (ARV) terbukti mampu mengendalikan progresifitas HIV dengan cara menghambat proses replikasi virus, sehingga viralload dapat ditekan dan jumlah CD4 rusak dapat diturunkan (Smeltzer \& Bare, 2010). Sedangkan terapi rumatan metadon bertujuan membantu Penasun berhenti menggunakan heroin bertahap dan mengurangi risiko penularan HIV dan virus lain terkait penggunaan narkotika suntik (Mattick et al., 2003).

Terapi antiretroviral (ARV) sebenarnya tidak dapat menyembuhkan HIV AIDS, namun terbukti mampu mengendalikan progresifitas HIV. ARV bekerja menghambat proses replikasi virus, sehingga viral load dapat ditekan dan jumlah CD4 rusak dapat diturunkan (Smeltzer \& Bare, 2010). Sejak 2010, sebanyak 84\% ODHA di dunia telah mendapatkan terapi ARV dan angka kematian menurun sebesar 42\%. Secara global hingga Juni 2015 dilaporkan 15,8 juta ODHA telah menjalani terapi ARV (UNAIDS, 2014). Di Indonesia sampai dengan September 2014 tercatat 14.631 ODHA telah mendapatkan terapi ARV (Kemenkes RI, 2014). Pada ODHA Penasun selain mendapatkan terapi ARV, ODHA juga mendapatkan terapi metadon.

Metadon disediakan pemerintah dalam program Terapi Rumatan Metadon (TRM) untuk pasien ketergantungan narkotika heroin (putaw) atau morfin. Metadon merupakan sintetis narkotika (opiat) berbentuk cairan sirup dengan efek sedatif yang tidak kuat serta tidak merusak organ hati dan ginjal. Efek kerja metadon rerata selama 24 jam di dalam tubuh, sehingga cukup di minum satu kali sehari. Metadon bekerja mengantikan fungsi heroin dalam otak sehingga pasien merasa nyaman tanpa merasakan gejala putus obat (sakaw). Terapi rumatan metadon bertujuan membantu Penasun berhenti menggunakan heroin bertahap dan mengurangi risiko penularan HIV dan virus lain terkait penggunaan napza suntik (Mattick et al., 2003). Metadon bukanlah sebagai obat penyembuh ketergantungan, karena pengguna metadon tetap merasakan ketergantungan opiat secara fisik.

Terapi ARV dapat diberikan pada ODHA penasun tanpa menghentikan metadon dan sebaliknya. Meski demikian beberapa ARV memiliki reaksi metabolisme yang berbeda terhadap metadon. Zidovudine (AZT), Nelfivavir dan Saquinavir dapat 
meningkatkan level metadon. Sedangkan Nevirapine (NVP) dan Efavirens (EFV), dan Ritonavir (RTV) dapat menurunkan level metadon sehingga menimbulkan efek seperti putus obat pada penggunanya (WHO, 2008; Kemenkes, 2012; Eluwa et al., 2012). Gejala putus obat yang dikeluhkan ODHA penasun seperti muntah, diare, kram perut, diaporesis, sakit kepala, tremor, dan cemas (Kemenkes RI, 2011). Sedangkan penggunaan ARV juga dilaporkan menimbulkan masalah pada kulit, hematologi, neurologis, rasa sakit, dan metabolik, serta gastrointestinal (Sharma et al., 2008; Eluwa et al., 2012).

Menjalani dua program terapi secara bersamaan dengan rutinitas dan risiko efek samping tentu menjadi beban bagi pasien. Keluhan fisik akan dipersulit oleh komplikasi masalah emosional, sosial dan etika (Smeltzer \& Bare, 2010). Berbagai sumber distres bisa muncul secara simultan bahkan terkadang bersamaan (Adewuya et al., 2010). Kondisi distres pada ODHA cenderung lebih sulit diatasi. Distres pada ODHA dapat mempercepat penurunan respon imun dan peningkatan replikasi virus (Robinson et al., 2003). Berbagai masalah fisik dan psikologis serta sosial yang mungkin dialami selama menjalani terapi ARV dan metadon berisiko menyebabkan terjadinya putus terapi dan ketidakpatuhan.

Sehingga tujuan penelitian ini yaitu untuk mempelajari fenomena pengalaman Orang Dengan HIV AIDS (ODHA) pengguna napza suntik (Penasun) selama menjalani terapi antiretroviral dan metadon.

\section{METODE PENELITIAN Desain Penelitian}

Penelitian ini merupakan penelitian kualitatif yang menggunakan pendekatan fenomenologi. Melalui pendekatan ini, peneliti berusaha untuk bisa menggambarkan, mengintreprestasikan serta menganalisis pengalaman hidup ODHA Penasun selama menjalani terapi ARV dan Metadon. Kegiatan yang dilakukan dalam pendekatan fenomenologi meliputi empat tahap yaitu bracketing, intuiting, analyzing, dan describing.

\section{Subek Penelitian}

Partisipan dalam penelitian ini diambil berdasarkan kriteria yang mengacu pada tujuan penelitian (purposive sampling) tepatnyadengan teknik snowball sampling. Partisipan merupakan ODHA dengan riwayat Pengguna Napza Suntik (Penasun) berusia 18 tahun ke atas dan telah menjalani terapi ARV dan terapi rumatan Metadon minimal 6 bulan, mampu berkomunikasi dengan baik, dan bersedia menjadi partisipan. Kriteria eklusi ini ditetapkan guna menghindari data bias antara masalah fisik dan psikososial akibat terapi ARV dan metadon dengan masalah akibat putus atau pengaruh dari Napza yang masih digunakan. Proses identifikasi kriteria calon partisipan dibantu oleh koordinator PTRM di Puskesmas Kedung Badak dan Puskesmas Bogor Timur.

Keseluruhan calon partisipan yang direkomendasikan berjumlah 13 orang.dua partisipan digunakan untuk uji coba pedoman wawancara, satu partisipan tidak dianalisis karena memiliki kriteria eklusi yaitu menggunakan metadon dengan jenis opiat suntik lainnya yang diketahui selama proses wawancara. Sehingga ada 10 partisipan yang dilibatkan sebagai subjek penelitian yang sebenarnya. Penetapan jumlah partisipan dinyatakan saturasi saat pengumpulan data tidak ditemukan lagi informasi yang bervariasi. Proses penelitian dilaksanakan di 2 satelit program terapi rumatan 
metadon di Kota Bogor yaitu Puskesmas Kedung Badak, dan Puskesmas Bogor Timur Kota Bogor Jawa Barat dengan difasilitasi oleh Dinas Kesehatan Kota Bogor.

\section{Metode dan Prosedur Pengumpulan Data}

Data pada penelitian ini dikumpulkan dengan metode: wawancara disertai catatan lapangan, observasi partisipan. Peneliti melakukan wawancara mendalam (indepth interview) semi berstruktur.Peneliti telah membuat pedoman wawancara (interview script) yang berisi beberapa topik penelitian. Pedoman wawancara telah dilakukan uji terhadap 2 orang partisipan dan telah direvisi. Pengembangan pertanyaan disesuaikan pada proses dan jawaban partisipan. Wawancara dilakukan 1-2 kali selama 30-60 menit pada setiap partisipan.Peran peneliti hanya membantu partisipan mengungkapkan pengalaman tanpa memberikan asumsi, opini, dan kritisi. Untuk meningkatkan akurasi pengumpulan data, peneliti menggunakan teknik pertanyaan terbuka (open-ended questions), merekam wawancara, dan membuat transkip verbatim.

\section{Analisis Data}

Informasi pada penelitian ini dianalisis secara simultan dengan proses pengumpulan data. Data diperoleh dari hasil wawancara, observasi partisipan, serta studi dokumentasi disalin dalam bentuk transkip. Peneliti menggunakan tahap analisis data Colaizzi. Tiap transkip hasil wawancara dianalisis secara terpisah sehingga dapat diperoleh pemahaman yang menyangkut keseluruhan esensi fenomena yang diteliti.

\section{Pertimbangan Etik}

Partisipan mempunyai hak untuk mendapatkan kenyamanan fisik maupun psikologis serta harus dilindungi selama proses penelitian berlangsung, sehingga dalam penelitian ini ditetapkan pertimbangan etika yang mengacu pada prinsip menghargai harkat dan martabat partisipan,prinsip memperhatikan kesejahteraan, keadilan (justice) untuk semua partisipan, persetujuan setelah penjelasan (informed consent).

\section{HASIL PENELITIAN}

\section{Karateristik Partisipan}

Partisipan dalam penelitian ini direkrut secara sukarela dan bersedia mengikuti wawancara yang dilakukan di ruangan tertutup. Karakteristik 10 partisipan secara demografi tinggal di beberapa kota berbeda, yaitu Jakarta, Bogor, dan Tangerang dengan jenis kelamin 3 perempuan dan 7 lelaki. Usia partisipan berkisar antara 30 hingga 40 tahun. Karaktersitik latar belakang pendidikan ada SMA, Sarjana (S1), dan Magister (S2).Variasi agama partisipan yaitu Islam, Kristen, Protestan dengansuku bangsa bervariasi yaitu, Sunda, Jawa, Batak, Betawi, Ambon, Bugis, dan Cina, serta Arab. Partisipan menceritakan bahwa mulai mengalami ketergantungan narkotika saat masih sekolah SMP dan SMA atau sebelum menikah. Lama menjalani terapi ARV berkisar 1 hingga 14 tahun. Partisipan sebagian telah menikah dan punya anak, serta ada yang berstatus janda dan duda.

Partisipan yang sedang menjalani terapi ARV di tempat yang berbeda yaitu di RS. Marzoeki Mahdi Bogor, RS Koda Tangerang, dan Puskesmas Jatinegara Jakarta, dan Puskesmas Cilandak Jakarta. Jenis ARV yang digunakan partisipan sesuai rekomendasi lini pertama yaitu: 2 NRTI + 1 NNRTI. Nama kombinasi obat yang saat ini digunakan yaitu, duviral dan neviral, duviral dan efavirenz, tenofavir + hiviral + neviral.Partisipan uga menjalani terapi Metadon di satelit metadon yang berbeda-beda, yaitu Puskesmas 
Kedung Badak dan Puskesmas Bogor Timur. Dosis metadon yang dijalani partisipan terendah $10 \mathrm{mg}$ dan tertinggi $260 \mathrm{mg}$.

\section{Tema Hasil Analisis}

Analisis penelitian kualitatif fenomenologi ini menggunakan analisis kualitatif colaizzi. Berdasarkan hasil analisis teridentifikasi 4 tema besar yang menjelaskan tentang pengalaman ODHA Penasun selama menjalani terapi ARV dan Metadon yaitu: (1)ODHA Penasun merasakan hidup normal kembali secara fisik. (2) ODHA Penasun memiliki kehidupan psikososial yang positif. (3) Perasaan Jenuh dengan rutintas dan kewajiban. (4) ODHA Penasun sering dihinggapi perasaan takut. (5) mengalami efek samping terapi ARVdan Metadon bersamaan.

\section{ODHA Penasun Merasakan Hidup Normal Kembali Secara Fisik}

Partisipan dalam penelitian ini mengungkapkan alasan yang membuat ODHA Penasun bisa bertahan menjalani terapi ARV dan metadon secara bersamaan yaitu karena merasakan hidupnya secara fisik sudah kembali normal atau mengalami perbaikan kondisi fisik. Selama menjalani terapi ARV dan metadon, partisipan mengungkapkan berbagai perbaikan kondisi fisik yang dialami meliputi kenyamanan karena terbebas dari gejala putus zat, tubuh terasa lebih nyaman dibanding sebelum menggunakan ARV dan metadon, serta proses penyembuhan infeksi oportunistik yang dialami lebih cepat sejak menggunakan ARV.

\section{Merasa Terbebas dari Gejala Putus Zat}

Manfaat utama yang diungkapkan partisipan terkait terapi metadon adalah terbebasnya dari gejala putus zat opiat. Berikut ungkapan partisipan:

“.....Kalo metadon manfaatnya langsung terasa ya.. Jelas perbedaannya kalau ngga minum metadon satu hari saja sakawnya (Gejala putus zat) gila-gilaan, Justru kalo ngga minum metadon ini, ya keluar semua (gejala putus zat) ya, he.. he..." (P3).

“......Emang bermanfaat nutupi sakawnya"... "Yang namanya sakaw kan harus nahan badan gitu kan, trus kata teman minum ini aja metadon,, ketutup emang tapi jadi keterusan"....(P7).

\section{Tubuh Terasa Lebih Nyaman}

Selama menjalani terapi ARV dan metadon, partisipan mengungkapkan bahwa tubuh terasa lebih sehat dan terbebas dari semua ketidaknyamanan fisik. Berikut ungkapan partisipan.

"Metadon, banyak juga manfaatnya. Paling ngga badan ngga pada sakit gitu”...

"Ya badan lebih enak ya. Soalnya kalo ngga pake metadon ni badan sakiiiit, tulang udah kayak apa-apa gitu”... “Aku pake ARV ya enakan lah badan gitu... sehat, paling nggak sehat lah sekarang. Aku bisa kayak begini tadinya sempat lemas lah begitu”... (P1).

\section{Lebih Cepat Proses Penyembuhan Infeksi Oportunistik}

Manfaat menjalani terapi ARV dapat meningkatkan daya tahan tubuhnya sehingga membuat partisipan bertahan hidup dan saat ini terhindar dari berbagai infeksi oportunistik yang pernah mereka alami. Berikut ungkapan partisipan:

"Kalo ARV itu... ya membantu... memang awal awal saya ngga ngerasain ya manfaatnya... Karena itu kan jangka panjang ya... eh... Terasanya waktu ketika gejala liver saya kumat, itu saya tetap mengkonsumsi ARV, disamping obat dokter 
ya... lebih cepat proses penyembuhannya"... "Dulu Hb pernah turun 3,7. Kalo normalnya 12 ya kalo ngga salah"... "Ngedrop saya, Hb nya turun, jadi badannya lemas, naik tangga sanggup, jalan juga payah"... (P3).

"Sebelum ARV karena saya kena TB dapat obat eh...bukan TB saya juga kena tokso (Toksoplasmosis virus)"... "Dirawat tahun 2007 mulai pake ARV”..."TB udah selesai lama”... (P7).

\section{ODHA Penasun Memiliki Kehidupan Psikososial yang Positif}

Partisipan dalam penelitian ini mengungkapkan alasan yang membuat ODHA Penasun bisa bertahan menjalani terapi ARV dan metadon secara bersamaan yaitu karena merasakan kehdiupan psikososial yang positif. Partisipan dalam penelitian ini mengungkapkan pengalamannya semenjak menggunakan terapi ARV dan metadon kehidupn psikososialnya lebih membaik dan positif. Partisipan memiliki pikiran yang lebih rasional, bergairah dan produktif dalam beraktivitas, serta merasakan hidup yang lebih stabil dibanding sebelum menjalani terapi ARV dan metadon.

\section{Merasa Memiliki Pikiran yang Rasional}

Partisipan menceritakan manfaat dari terapi ARV dan Metadon bisa membuat partisipan merasa mampu berpikir normal atau lebih baik dibanding sebelum menjalani terapi ini.

"Pola pikir juga berubah gitu”... "Udah gitu aku udah juga ngga, kalo dulu kan sempat kayak (Memperlihatkan ekspresi bingung)" (P1)

"Jadi kayak orang normal aja gitu, caranya pikirnya balik lagi ke fungsi sosial" (P2).

\section{Bergairah dan Produktif dalam Beraktivitas}

Munculnya gairah atau semangat bekerja agar lebih produktif terungkap sebagai suatu indikasi bahwa kehidupan para partisipan sudah lebih positif. Berikut ungkapan partisipan.

"Saya itu ngerasain dulu kalo kerja, saya ngga bisa kerja bener kalo sebelum make gitu,tapi kalo sudah kena (metadon), kerjaan apa saja pasti beres”... (P8).

"Alhamduliilah ikut program terapi rumatan ini semua terkendali, produktivitasnya juga"... "Saya ngerasain ini benar benar sangat menguntungkan, dari segi hal produktifitasnya"..."Banyak sih dampak kita bergairah lagi dalam beraktivitas. Metadon juga hampir sama"... "Alhamdulillah masih bisa dikendalikan karena ada usaha kecil kecilan"... (P10).

\section{Merasa Hidup Lebih Stabil}

Partisipan mengungkap bahwa saat ini memiliki hidup yang lebih stabil jika dibandingkan saat masih menjadi pengguna napza suntik dan belum menjalani terapi ARV. Berikut ungkapan partisipan:

"Kebetulan aku dapatnya, kebetulan pas kali ya. Memang kemaren sakit dan lagi stress gitu, sekarang jadinya... semuanya udah seimbang lagi”... udah normal lagi kayaknya hidup. Jadi bisa kayak gini, bisa jalan sana sini bisa ngurusi rumah”.... (P1).

"Saya bisa merapikan hidup, yang tadinya berantakan, yang kepercayaan ngga ada, kepercayaan dari keluarga, dari istri, dari lingkungan ngga ada. Akhirnya saya bisa ngebangun kembali, kasarnya badan saya asalnya metadon ketelan, Cuma ngga 
terlalu dikit dikit cari uang untuk beli metadon. Dengan yang saya rasaian dengan dosis kecil harga 7.000 ngerasa sudah cukuplah... Cuma maindsetnya ditujuin "gue mau ngebersin hidup gw dulu neh" baru masalah social beres, kerjaan beres, pokok semua yang tadinya berantakan kembali lagi"... "Kualitas hidup lebih baik nurut saya".... (P4)

\section{Perasaan Jenuh dengan Rutintas dan Kewajiban}

Secara psikologi partisipan mengungkapkan perasaan ingin bebas dari metadon dan partisipan menyadari tidak bisa terbebas dari ARV. Meskipun mereka mengungkapkan dengan metadon saat ini hidup terasa lebih normal dibanding sebelum menggunakan metadon namun dari ungkapan yang disampaikan tersirat perasaan jenuh. Partisipan menceritakan perasaan terkekang seperti tahanan kota, jenuh terutama pada metadon dan ARV yang harus dikonsumsi keduanya setiap hari, serta penuh dengan kewajiban melapor sebagai pengguna metadon.

\section{Merasa Seperti Tahanan Kota}

Partisipan mengungkapkan pengalaman kejenuhannya selama menggunakan ARV dan metadon serasa seperti "tahanan kota" yang tidak bisa kemana-mana sehingga ruang gerak terbatas. Berikut ungkapan partisipan:

"Kalo metadon rasanya jadi kayak tahanan kota, ngga bisa kemana mana jauh"...

“...Kayak misalnya mau keluar kota atau kemana kan susah”... (Minta izin THD (take home doses)?) "Minta izin aja, tapi kan ngga bisa lama-lama, paling berapa hari gitu”... (P2).

"Mau ke luar negeri kan ngga bisa, kan harus lama. Kalo obat botol terlalu banyak gitu ngga boleh terlalu banyak dibawa”... (P8).

\section{Metadon Lebih Membosankan Dibanding ARV}

Kejenuhan dan kebosanan lebih banyak terungkap pada rutinitas minum metadon dibanding ARV. Berikut ungkapan partisipan:

"Bosannya karena saya sudah 4 tahun metadon, justru ARV karena sudah hampir 14 tahun justru ngga bosan, karena sudah biasa” (P6)

"Capek juga pake metadon, bosan juga... Trus kadang bosan mau minum juga udah blenak, bosan lah udah 2 tahun gini kan keblenek banget rasanya"... "Rasa bosan buat minumnya gitu... ihh aduhh... (sambal bergidik), Baru liat aja kayaknya udah eneg”... “... Capeklah tiap hari musti minum obat”... (P1).

\section{ODHA Penasun Sering Dihinggapi Perasaan Takut}

Partisipan menceritakan perasaan takut akan terjadinya putus zat, serta takut jika ketergantungan metadon yang dijalani akan terjadi seumur hdup.

\section{Ketakutan Akan Putus Zat}

Siksaan putus zat metadon lebih menyiksa lebih lama dibanding dengan putus zat heroin itu yang membuat partisipan takut. Berikut pernyataan ungkapan ketakutan partisipan:

"Mau ngga mau kita butuh, kalo ngga minum kita bisa sengsara, tersiksanya bukan sehari dua hari, bisa dua tiga minggu, wah ngga sanggup deh tersiksanya. Dulu juga pernah coba berhenti metadon, saya tahan badan 3 minggu. 2 minggu pertama ngga tidur, minggu ketiganya itu wah tidur kayak tidur ayam, badan sakit semua udah 
ngeri saya... itu dulu dosis 80 neh udah 110 tambah gila lagi ntar... wah ngga berani saya”... (P3).

“..Ada ketakuktan sakaw”... "Jadi bener bener harus... ya gitulah harus ada".... "kalau ARV misalnya aku telat seminggu itu masih mendingan ngga berasa iya kan? Kalo metadon? Telat sejam saja aku udah teler"... (P1).

\section{Takut Ketergantungan Metadon Seumur Hidup}

Partisipan mengungkapkan ketakutan jika akan mengalami ketergantungan seumur hidup selalu menghinggapi pikiran mereka. Berikut ungkapan partisipan:

"Ya khawatir takut apakah ini kertergantungan seumur hidup atau ya.. kadangkadang terlintas seperti itu”... (P10)

"Capeklah tiap hari musti minum obat, Pengennya sih berhenti, kalo berhenti pengen sehat, gimana sih orang mau berhenti minum obat, sehat. Pengennya sih sehat itu berhenti selesai. ARV saja satu kek metadonnya ngga usah, kalo ARVnya ngga bisa berhenti. Pengennya sih dosisnya dikurangi. Katanya kan dosisnya turun turun terus habis".... "Dosis tertinggi 220 kemaren sekarang stabil di 90 ntar pengennya minta turun lagi pengennya biar cepat selesai metadonnya” (P1).

\section{ODHA Penasun Mengalami Efek Samping Terapi ARVdan Metadon Bersamaan}

Selama menjalani terapi ARV dan metadon partisipan mengungkapkan beberapa efek samping yang dialami seperti: gigi hitam dan keropos, sulit buang air besar, gatal dan ruam pada kulit, serta gangguan disfungsi seksual.

\section{Gigi Hitam dan Keropos}

Kerusakan gigi diungkapkan berdasarkan pengalaman partisipan yang mengaku tidak tahan terhadap rasa pahit sehingga jika minum metadon selalu minta sirup pemanisnya dibanyakan. Berikut ungkapan partisipan:

“... Kemudian masalah gigi juga lama-lama jadi habis, makan gigi dia (Metadon)... keropos..keropos... lama-lama patah habis, ini udah habis semua gigi saya"...

"Mungkin bahan kimia dalam metadon itu ya, bikin gigi rusak, karena kita kan minumnya secara oral. Melewati gigi mungkin nempel di gigi, kurang ngertilah saya, yang jelas memang gigi habis, rata rata peminum metadon giginya ngga ada yang benar"... (P3).

\section{Sulit Buang Air Besar}

Partisipan mengungkapkan bahwa semenjak memulai metadon sering mengalami kesulitan buang air besar (BAB). Berikut ungkapan partisipan:

"Pengaruh metadon ya jadi sulit untuk puff (Buang air besar) ya"... "Sulit untuk puff (buang air besar), yang saya rasain untuk puff ya, 2 minggu paling cuma 2 kali 3 kali lah... nah.. itu efeknya jadi bikin ambeyen. Karena itu keras mau ngga mau kita paksain, kalo ngga jadi ngga enakkan di perut”... (P3).

\section{Ruam dan Gatal pada Kulit}

Pengalaman partisipan yang diungkapkan yaitu mengalami dermatitis dimana munculnya nodul nodul kemerahan yang gatal disertai ruam-ruam dan nanti menghitam pada kulit tangan dan punggung bagian belakang. Berikut ungkapan partisipan:

"Beehhh.... kulit ni sekarang, aku neh tuh, pada gatal gatal (sambil mempelihatkan kulit yang bermasalah) neh aku neh juga mau berobat neh... Belum lama ada ehh.. udah dua bulan kali ini hampir dua bulan ini".... (P1). 
"Sempat badannya merah-merah, sempat ruam ruam juga"...(Bentuknya?).. "Bulat bulat gitu deh... merah kayak yang bengkak tapi merah.... Ada yang sebesar koin ada yang kecil dari koin ada yang gede gede"... (P4).

\section{Gangguan Fungsi Seksual}

Partisipan mengungkapkan masalah terkait gairah seks (libido) dan kemampuan ejakulasi serta orgasme yang mereka alami selama menggunakan metadon dan ARV. Berikut ungkapan partisipan:

"Berpengaruh ya itu mengurangi (libido) ya... menurunkan (libido)... Saya rasa metadon cenderung mereka juga... pengaruh dari metadon”... "Ejakulasinya biasa ya... mungkin ada sedikit bermasalah ehhh.... Cepat... cenderung lebih cepat ya”... (P3).

"Cuma ngga kayak dulu... kalo dulu kan bisa kencang terus kalau sekarang harus istirahat dulu, Ejakulasi kalo dulu lama sekarang cepat”... (P7).

"Itu metadon... libidonya menurun”... (Bagaimana dengan ejakulasi?) “Enggak.... malah enggak ejakulasi”... (P8).

\section{PEMBAHASAN}

\section{ODHA Penasun Merasakan Hidup Normal Kembali Secara Fisik}

Setiap terapi yang dijalani tentu diharapkan memberi manfaat bagi penggunanya, begitu pun terapi metadon. Metadon merupakan agonis sintetik opiat kuat yang bekerja menekan fungsi susunan saraf pusat sehingga mempunyai efek analgesik yang kuat (BNN, 2008; Padila, 2012). Pengalaman partisipan mengungkapkan bahwa terapi metadon mampu memberikan kenyamanan secara fisik. Kenyamanan fisik yang diungkapkan yaitu terbebasnya dari gejala putus zat seperti nyeri di tulang belakang dan persendian, bahkan nyeri pada seluruh tubuh yang disertai perasaan gelisah. Setelah minum metadon, badannya lebih enak tanpa rasa nyeri, dan terasa lebih segar saat bangun pagi hari.

Berdasarkan pengalaman partisipan yang mengungkapkan metadon mampu memberikan kenyamanan fisik, maka beberapa partisipan mempersepsikan bahwa metadon mampu menggantikan fungsi heroin dalam otak penggunanya. Partisipan memperoleh kenyamanan tanpa merasa sakaw dan sugesti (cravings) meski tidak menggunakan heroin atau morfin. Persepsi yang diungkapkan tersebut didukung dengan hasil meta analisis Mattick et al., (2003) yang menyimpulkan bahwa metadon terbukti efektif dalam mengembangkan pengobatan ketergantungan penggunaan heroin.

Selain penggunaan metadon, perbaikan kondisi fisik juga diperoleh dari manfaat terapi ARV. Penggunaan antiretroviral pada pengguna metadon dapat dimulai tanpa harus menghentikan metadon, begitupun sebaliknya. Terapi Antiretroviral (ARV) mulai diperkenalkan sejak tahun 1996 (Kemenkes RI, 2012). ARV bekerja dengan cara menghambat progresifitas replikasi HIV dalam tubuh ODHA, sehingga jumlah viral load dapat ditekan dan jumlah CD4 rusak dapat diturunkan (Smeltzer \& Bare, 2010). Manfaat utama dari penggunaan ARV yaitu memperbaiki daya tahan tubuh ODHA. Pengalaman partisipan penelitian ini menceritakan bahwa sebagian besar saat memulai terapi ARV mengalami penurunan jumlah CD4 namun setelah dan selama menjalani terapi ARV, CD4 berangsur meningkat.

Berdasarkan rekomendasi Kemenkes RI (2012) pertimbangan pemberian terapi ARV dimulai yaitu pada pasien yang memiliki jumlah CD4 $<350 \mathrm{sel} / \mathrm{mm}^{3}$ tanpa memandang stadium klinisnya atau didasarkan pada pertimbangan kondisi klinis 
penderita HIV. Rekomendasi Kemenkes (2012) bahwa pada ibu hamil HIV (+) atau pasien yang mengalami infeksi oportunistik seperti TB aktif, dan koinfeksi hepatitis B, untuk segera dimulai terapi ARV tanpa melihat jumlah CD4 pasien tersebut. Partisipan penelitian ini mengungkapkan bahwa mereka memulai terapi karena mengalami infeksi oportunistik seperti tuberkulosis paru, kandidiasis oral, hepatitis, dan toksoplasmosis. Seorang partisipan yang baru saja melahirkan juga mengungkapkan bahwa selama hamil selalu minum ARV.

Secara nyata ARV digunakan sebagai terapi pendukung untuk menurunkan angka kesakitan seperti tuberculosis TB, HBV dan HCV (WHO, UNAIDS \& UNODC, 2005). Pengalaman keberhasilan ODHA menjalani terapi ARV termonitor dari hasil peningkatan jumlah CD4 yang partisipan ungkapkan. Perbaikan sistem imun akan meningkatkan kemampuan tubuh melawan mikroorganisme penyebab penyakit, sehingga ODHA mampu pulih dan terhindar dari infeksi oportunistik lainnya selama menggunakan terapi ARV.

Pemberian terapi ARV harus memperhatikan aspek efektifitas, aspek interaksi obat, toksisitas (efek samping), aspek harga obat, serta aspek kepatuhan. Terapi ARV saat ini diberikan dalam bentuk kombinasi atau dikenal dengan istilah HAART (Highly Active Antiretro-viral Therapy). Pengobatan lini pertama yang ditetapkan pemerintah yaitu kombinasi ARV dengan paduan: 2 NRTI + 1 NNRTI (Kemenkes RI, 2012).

Partisipan pada penelitian ini menyebutkan nama jenis obat ARV yang mereka gunakan yaitu duviral dan neviral (P1; P5; P7; P8; P9; P10), duviral dan efavirenz (P2; $\mathrm{P} 4$; P6), hiviral dan neviral serta tenofovir (P3), Teno3 in 1 (P5). Secara umum jenis obat yang digunakan partisipan merupakan pengobatan lini pertama yang direkomendasikan di Indonesia.

Terapi ARV yang digunakan partisipan seperti duviral merupakan gabungan dari 2 obat golongan NRTI yaitu Zidovudine (AZT) dan Lamivudine (3TC), sedangkan hiviral hanya mengandung 1 NRTI yaitu Lamivudine saja, begitupun Tenofovir (TDF) merupakan 1 NRTI. Sedangkan Nevirapine/Neviral (NVP) dan Efavirenz (EFV) merupakan golongan obat NNRTI. Sehingga jika dianalisis kombinasi ARV yang diterima sebagian besar partisipan yaitu duviral yang dikombinasikan dengan Neviral (Nevirapine) atau Efavirenz (EFV). Pola terapi ini semuanya memenuhi kriteria kombinasi pengobatan lini pertama yaitu 2 NRTI + 1 NNRTI. Hasil penelitian ini juga sama dengan hasil penelitian yang dilakukan Yuniar (2012), bahwa terapi ARV lini pertama yang merupakan kombinasi ARV Duviral-Neviral dan Duviral-Efavirenz secara umum banyak digunakan saat ini.

Secara umum terapi ARV yang dijalani partisipan pada penelitian ini juga telah sesuai dengan paduan ARV yang direkomendasikan pemerintah pada penasun aktif atau pengguna Napza yaitu: Zidovudine (AZT) atau Tenofovir (TDF) + Lamivudine (3TC) + Efavirenz (EFV) atau Nevirapine (NVP) (Kemenkes RI, 2012). Sehingga sampai saat ini partisipan mengungkapkan manfaat yang positif terhadap pengobatan ARV lini pertama yang partisipan gunakan. Peningkatan daya tahan tubuh ditandai dengan terjadinya peningkatan CD4 dan pulihnya serta terhindar dari berbagai infeksi oportunistik dirasakan partisipan dalam pengalaman yang mereka sampaikan selama menjalani terapi ARV.Efektifitas keberhasilan terapi metadon dan ARV yang dijalani ODHA Penasun salah satunya bisa dilihat dari perbaikan kualitas hidup ODHA Penasun secara psikososial. 


\section{ODHA Penasun Memiliki Kehidupan Psikososial yang Positif}

Partisipan dalam penelitian ini mengungkapkan pengalamannya bahwa semenjak menggunakan terapi ARV dan metadon kehidupan psikososialnya lebih positif. Berdasarkan hasil wawancara terungkap bahwa partisipan telah memiliki keinginan dan kemampuan untuk bekerja secara produktif, mampu berpikir normal, merasakan hidup mereka lebih stabil, serta membaiknya fungsi sosial yang mereka jalani.

Sesuai dengan harapan yang disampaikan UNODC (2015) bahwa ARV merupakan kesempatan besar bagi ODHA untuk memperbaiki prognosis dan meningkatkan kualitas hidupnya. Kesempatan besar ini juga telah dimanfaatkan oleh partisipan penelitian ini untuk meningkatkan kualitas hidupnya. Partisipan nomor 6 mengungkapkan bahwa telah menggunakan ARV selama 14 tahun dan sekarang bisa bekerja mencari uang dan terhindar dari tindakan kriminal, dan merasa seperti manusia normal bukan seperti "zombie" (P6). Begitupun sembilan partisipan lainnya juga mengungkapkan manfaat yang positif tentang pencapaian kestabilan hidup mereka seperti merasakan pola pikir yang sudah berubah lebih baik, bangun tidur tidak memikirkan heroin lagi, bisa banyak fokus, kehidupan keluarga lebih bisa terurus, punya keinginan bekerja, sudah bisa mencari uang secara mandiri, dan bisa menyelesaikan pekerjaan dengan lebih baik, dan lain sebagainya.

Berbagai ungkapan pengalaman partispan tersebut selaras dengan Mattick et al., (2003) yang menyimpulkan bahwa metadon terbukti efektif dalam mengembangkan pengobatan ketergantungan, mengurangi tindakan kriminal, dan penggunaan heroin. Sehingga pengguna metadon memiliki kesempatan dan peluang untuk memperbaiki dan menstabilkan kehidupannya. Partisipan mengungkapkan PTRM mampu membantu mereka mengurangi dampak buruk, dan tindak kejahatan kriminal yang merugikan orang lain seperti, pencurian, perampokan dan lain sebagainya yang bisa mereka lakukan saat aktif sebagai pecandu narkotika guna mendapatkan uang untuk membeli narkotika.

Pengalaman para partisipan penelitian ini didukung hasil penelitian kuantitaif di RSKO Jakarta dan RS Sanglah Bali bahwa dari 100 kasus yang menerima terapi rumatan metadon menunjukkan perbaikan kualitas hidup secara fisik, psikologis dan sosial, angka kriminalitas dan depresi juga dapat diturunkan setelah ODHA menjalani terapi rumatan Metadon tersebut (SK Menkes RI, 2006).

\section{Perasaan Jenuh dengan Rutintas dan Kewajiban}

Para partisipan telah mengungkapkan kenyamanan secara fisik sebagai manfaat metadon dan ARV yang telah membebaskan mereka dari ketidaknyamanan putus zat dan berbagai infeksi oportunistik. Namun secara psikologis partisipan mengungkapkan berbagai beban psikologis baru selama menjalani terapi ARV dan metadon. Ungkapan yang bernuansa keterkekangan, kebosanan, kecemasan dan ketakutan terungkap secara sadar dalam cerita yang disampaikan partisipan.

Perasaan keterkekangan yang diungkapkan partisipan yaitu merasa sebagai "tahanan kota" sehingga ruang gerak terbatas, kesulitan untuk melakukan perjalan jauh dalam waktu lama, kesulitan untuk kegiatan ke luar negeri karena keterbatasan perizinan membawa metadon dalam jumlah banyak. Selain ruang gerak yang terbatas, partisipan juga mengungkapkan perasaan bosan atau jenuh atas rutinitas minum obat setiap hari. Menurut Sugiharti et al., (2014) rasa bosan dan jenuh minum obat bisa menjadi faktor penghambat kepatuhan ODHA dalam terapi ARV. 
Kebosanan yang diungkapkan partisipan lebih banyak karena bosan minum metadon bukan ARV. Karena yang dipersepsikan partisipan ARV sudah harga mati dan bahkan karena sudah lama menggunakan ARV sehingga merasa sudah menjadi suatu kebiasaan. Namun minum metadon meski mencegah terjadinya gejala putus obat namun sangat terasa bosan dan memuakan.

Partisipan mengungkapkan kejenuhan dengan rutinitas harus minum ARV setiap hari. Kejenuhan tersebut biasanya terjadi bila ODHA sudah 6 bulan menjalani terapi ARV. Hal ini dikarenakan ODHA merasa sudah sehat atau sudah merasa bosan setiap hari minum obat (Sugiharti et al., 2014). Kebosanan yang diungkapkan partisipan dalam penelitian ini, selain bosan terhadap rutinitas minum obat juga bosan dengan aktivitas mengunjungi layanan metadon.

\section{ODHA Penasun sering Dihinggapi Perasaan Takut}

Selain perasaan terkekang dan bosan, partisipan juga mengungkapkan beban ketakutan yang mereka rasakan. Ketakutan akan gejala putus zat jika berhenti minum metadon, ketakutan akan kematian, dan ketakutan akan ketergantungan metadon seumur hidup. Ungkapan tersebut sama seperti hasil penelitian Sugiharti et al., (2014) yang mengemukakan bahwa selain perasaan bosanjuga menjadi faktor penghambat kepatuhan ODHA dalam obat ARV. Meskipun hingga saat ini partisipan mengaku patuh untuk minum metadon dan ARV namun kebosanan yang diungkapkan tetap dapat menjadi faktor risiko terjadinya putus terapi.

Berbagai beban psikologi yang dihadapi partisipan seperti kejenuhan, ketakutan merupakan wujud distress bahkan bisa berisiko terjadinya depresi. Distres pada ODHA bisa bersifat kronis yang bisa memperburuk kondisi kekebalan tubuh serta kesehatan fisik dan emosional ODHA (Lerner et al., 2013). Kondisi lanjut dari beban ketakutan yang dialami partisipan adalah depresi. Bahkan ada satu partisipan (P4) mengungkapkan pernah 2 kali melakukan upaya bunuh diri dengan mencoba menabrakkan diri ke kereta yang sedang berjalan dan dengan cara memotong pembuluh darah di lengan. ODHA yang mengeluhkan efek samping fisik yang berat sehingga kualitas hidupnya menurun bahkan terjadi ancaman bunuh diri (Sherr, 2007).

Selain itu ketakutan akan kematian dan ketakutan akan ketergantungan metadon seumur hidup yang juga terungkapkan oleh partisipan juga akan semakin membuat beban psikologi ODHA Penasun bertambah. Seperti yang diungkapkan (Woodward \& Pantalone, 2012), bahwa efek negatif yang umum ditemukan pada ODHA yang mengkonsumsi ARV yaitu depresi (depression) dan kecemasan (anciety). WHO pun mempertegas bahwa depresi merupakan gangguan psikologis yang dilaporkan banyak dialami ODHA Penasun (WHO, 2008).

Perasaan bersalah atau penyesalan yang dirasakan memicu semangat partisipan untuk lebih baik lagi. Semua partisipan menyadari bahwa ARV adalah harga mati bagi mereka namun metadon hanya merupakan terapi substitusi dari ketergantungan opiat yang mereka alami. Persepsi ini membuat partisipan mempunyai harapan dan keinginan untuk terbebas sebebasnya dari ketergantungan zat opiat metadon tersebut. Hal tersebut terungkap dari beberapa ungkapan partisipan dalam penelitian ini. Keluarga, istri, terutama anak menjadi sumber motivasi utama yang diungkapkan partisipan. Keinginan memberikan contoh perilaku yang baik bagi anak, keinginan untuk bisa membesarkan anak hingga dewasa. Membuat para partisipan bertahan untuk tetap sehat dan berperilaku hidup sehat dan ingin secapatnya bebas dari terapi metadon. 
Selama menjalani terapi ARV dan Metadon, partisipan menceritakan berbagai masalah fisik dialami terkait efek penggunaan terapi tersebut. Masalah fisik yang terungkap dibedakan dengan masalah fisik akibat putus zat opiat yang juga partisipan pernah rasakan selama ini. Meskipun partisipan menggunakan metadon namun gejala putus zat pada kondisi tertentu masih bisa mereka alami. Saat kadar metadon menurun maka akan menimbulkan gejala putus obat pada ODHA (Elinore, 2007; WHO, 2008).

\section{ODHA Penasun Mengalami Efek Samping Terapi ARV dan Metadon Bersamaan}

Selain mengalami masalah psikososial selama menjalani terapi ARVdan metadon, partisipan juga merasakan masalah fisik dan efek samping metadon selama dijalani.Secara umum partisipan mampu mengenal masalah fisik putus zat yang mereka alami seperti perasaan nyeri persendian dan seluruh badan, kegelisahan, hingga ketidakmampuan beraktivitas, berkeringat banyak, dan lain sebagainya. Gejala putus zat lainnya yang dikemukan Kemenkes RI (2012) diantaranya muntah, diare, kram perut, berkeringat banyak (diaporesis), sakit kepala, tremor, dan cemas. Namun pada penelitan ini partisipan tidak ada yang melaporkan gejala muntah, diare, dan kram perut selama masa putus zat metadon.

Meskipun ARV tidak kontra indikasi dengan metadon namun interaksi kedua obat perlu diperhatikan. Pemberian ARV golongan NNRTI seperti Efavirens (EFV), Nevirapine (NVP), atau Ritonavir (RTV) pada ODHA Penasun bisa menyebabkan penurunan konsentrasimetadon dalam darah danmenyebabkan munculnya gejala putus zat opiat (Kemenkes RI, 2012). Keseluruhan partisipan dalam penelitian ini memperoleh ARV golongan NNRTI yaitu Nevirapine (Neviral) dan Efavirenz.

Obat ARV golongan NNRTI seperti Efavirenz (EFV), Nevirapine (NVP) atau Ritonavir (RTV), mempunyai efek induksi cytochrome P450 (CYP3A4). Cytochrome merupakan enzim yang memetabolisme metadon dalam plasma darah. Sehingga jika ARV golongan ini digunakan bersamaan dengan metadon, maka dapat meningkatkan metabolisme metadon yang berakibat terjadinya penurunan konsentrasi metadon dalam plasma darah. Sehingga pada penggunaan NNRTI perlu dinaikkan dosis metadon ke level konsentrasi yang mampu ditoleransi sehingga gejala putus zat dapat dihindari.

Masalah fisik selain gejala putus zat opiat yang pernah dirasakan partisipan yaitu masalah fisik terkait reaksi obat ARV dan metadon. Masalah fisik yang mampu dikenali partisipan terkait penggunaan ARV dan metadon yang meliputi masalah pada saluran cerna, masalah pada kulit dan jaringan adiposa, masalah pada sistem reproduksi, serta masalah pada persayarafan.

ARV bisa menyebabkan efek Adverse drug reaction (ADR) pada sistem gastrointestinal sebesar 20\% (Sharma et al., 2008). Pada penelitian ini, partisipan tidak ada yang mengungkapkan masalah saluran cerna terkait pemakaian ARV, sehingga hal ini berbeda dengan penelitian tersebut diatas. Meskipun diketahui bahwa Zidovudine mempunyai efek samping yaitu intoleransi gastrointestinal seperti mual dan muntah (Kemenkes RI, 2012). Namun tidak ada partisipan yang mengungkapkan keluhan mual dan muntah terkait ARV. Justru partisipan mengenal masalah mual dan muntah terjadi pada awal menggunakan metadon. Masalah saluran cerna yang dikenali partisipan yaitu kerusakan gigi dan konstipasi. Masalah-masalah tesebut dipersepsikan partisipan sebagai efek dari penggunaan metadon.

Metadon mempunyai efek mirip heroin. Metadon menimbulkan efek relaksasi pada otot polos usus sehingga bisa menyebabkan konstipasi. Respon metadon berbedabeda pada setiap individu (BNN, 2008). Hal ini dipahami benar oleh para partisipan 
terlihat dari beberapa ungkapan yang menyebutkan bahwa konstipasi yang dialami sama pada saat dulu menggunakan heroin. Konstipasi yang dialami bahkan dalam dua minggu hanya 2- 3 kali buang air besar.

Selain masalah konstipasi, kerusakan gigi yang diungkapkan juga oleh partisipan yaitu awalnya gigi menghitam lalu keropos. Kondisi ini diprediksi terjadi karena penggunaan sirup manis pekat selama minum metadon. Kondisi diperberat dengan kebiasaan oral higien partisipan yang kurang dalam perawatan gigi dan mulut salama mengkonsumsi metadon cair secara oral. Efek metadon yang menstimulasi mediator peradangan sehingga menyebabkan kerusakan pada lapisan email gigi.

Masalah pada kulit dan adiposa yang diungkapkan partisipan, yaitu munculnya dermatitis, ruam-ruam, gatal-gatal, dan lipodistropi serta banyak berkeringat. Kondisi ini terjadi karena metadon menstimulasi pelepasan mediator kimia tubuh seperti histamin yang dapat menimbulkan efek seperti diaporesis, skin rush, gatal pada kulit (Preston \& Doverty, 2006). Sehingga sangat berisiko pengguna metadon mengalami gangguan pada kulit sebagai manifestasi reaksi tersebut.

Kemungkinan penyebab munculnya masalah pada kulit yang dialami partisipan yaitu disebabkan sebagai reaksi obat ARV. Karena ARV seperti Zidovudine, Efavirenz dilaporkan mempunyai efek samping menimbulkan pigmentasi kulit dan kuku serta ruam-ruam pada kulit (Kemenkes, 2012). Penelitian Sugiharti et al., (2014) juga menyebutkan bahwa Duviral-Efavirenz menyebabkan ruam-ruam pada kulit. Penelitian lainnya terhadap 100 pasien yang menjalani terapi ARV yaitu menunjukkan reaksi gangguan pada kulit sebesar $(44,4 \%)$. Keluhan kulit yang dirasakan yaitu hiperpigmentasi $(14,4)$ pada mulut dan kuku, dan rash $(13,3 \%)$ (Sharma et al., 2008). Berdasarkan hal tersebut bisa dimaknai bahwa masalah pada kulit partisipan tersebut terkait dengan penggunaan ARV dan Metadon.

Masalah pada terkait fungsi seksual dan reproduksi juga terungkap oleh partisipan perempuan yaitu gangguan menstruasi yang meliputi perubahan pola yang memanjang dan durasi menstruasi yang memendek. Menstruasi terkadang terjadi 3 bulan sekali. Jikapun terjadi menstruasi hanya berlangsung selama 3-5 hari saja. Pengalaman partisipan perempuan tersebut mendukung penelitian Preston \& Doverty (2006) yang menyimpulkan bahwa umumnya pengguna metadon mengalami gangguan menstruasi.

Partisipan pria juga mengaku mengalami gangguan fungsi seksual yaitu mengalami penurunan libido, dan penurunan kemampuan ereksi serta ejakulasi yang cenderung cepat bahkan sulit mencapai ejakulasi. Berbagai pengalaman partisipan kemungkinan disebabkan oleh penggunaan metadon dan ARV karena, menurut hasil penelitian Preston \& Doverty (2006) menyebutkan bahwa pengguna metadon umumnya mengalami penurunan libidio serta perasaan lemah. Selain itu penelitian lainnya juga menyebutkan bahwa terapi ARV khususnya NNRTI berdampak pada penururun hormon testosterone dan estradiol sehingga menyebabkan (48\%) penurunan libido dan (25\%) mengalami gangguan ereksi (Callazos et al., 2000).

Munculnya berbagai masalah fisik sebagai reaksi obat yang merugikan dipengaruhi oleh berbagai faktor risiko. Penelitian yang dilakukan Eluwa et al., (2012) menyimpulkan beberapa faktor risiko ADR diantaranya usia lebih dari 45 tahun sangat berisiko, namun keluhan mulai muncul pada usia 15-45 tahun. Jenis kelamin lelaki lebih berisiko dibanding perempuan. Jenis regimen berbasis Zidovudine lebih berisiko dibanding regimen lainnya. Lama pengobatan 6-12 bulan sangat berisiko mengalami reaksi ARV yang merugikan dibanding usia 0-6 bulan. 
Faktor risiko pada partisipan penelitian ini yaitu sebagian besar partisipan berjenis kelamin lelaki dan berada pada rentang usia 30 hingga 40 tahun. Partisipan juga banyak menggunakan zidovudine (AZT) dalam terapi lini pertamanya. Partisipan dalam penelitian ini ditetapkan sudah menjalani terapi ARV dan metadon minimal 6 bulan. Partisipan telah menggunakan ARV selama rentang 1 hingga 14 tahun. Karena menurut onset dan distribusi reaksi obat ARV yang merugikan paling banyak dilaporkan pada lama pengobatan $12-24$ bulan $(45,1 \%)$, selanjutnya $6-12$ bulan $(21,57 \%)$, sedangkan lebih dari 36 bulan hanya (1,96\%) (Eluwa et al., 2012). Artinya semakin lama menggunakan ARV semakin minimal reaksi ARV merugikan yang ditemukan.

Faktor risiko ARV yang digunakan partisipan yang berisiko menimbulkan efek merugikan, yaitu penggunaan duviral (Zidovudine dan Lamivudine) dengan Efavirenz. Sesuai dengan hasil penelitian lainnya, secara umum Zidovudine (AZT), Stavudine (d4T), dan Efavirenz, serta Tenofovir dilaporkan menimbulkan efek samping (Sharma et al., 2008; Eluwa et al., 2012). Duviral-Efavirenz menyebabkan badan lemas, kaki lemas sampai tidak bisa berjalan, ruam kulit, demam, pusing, mual, dan lemas (Sugiharti et al., 2014).

\section{SIMPULAN}

Terapi ARV dan metadon yang dijalani ODHA penasun memberikan manfaat terhadap perasaan mencapai kehidupan yang normal kembali baik secara fisik maupun psikososial. Namun khusus metadon, terlepas dari manfaat fisik yang dirasakan, secara psikologis ODHA Penasun ingin terbebas dari terapi metadon sehingga hanya menjalani terapi ARV saja. ODHA Penasun juga memiliki kemampuan melakukan penyesuaian terapi metadon dengan respon tubuh guna memperoleh manfaat terapi yang diinginkan dan menghindari efek samping terapi yang tidak diinginkan.

\section{SARAN}

Upaya pelayanan kesehatan diharapkan tidak hanya berorientasi pada upaya kuratif namun berdasarkan hasil penelitian ini diharapkan bisa dikembangkan permberdayaan diri ODHA secara mandiri untuk siap menjalani terapi ARV dan metadon. Perlu dikembangkan upaya promotif dan preventif bagi ODHA Penasun sebelum dan selama menjalani terapi ARV dan metadon, sehingga masing-masing ODHA memiliki kemampuan diri dalam mengenal dan mengambil keputusan atas setiap masalah fisik dan psikologis yang mereka hadapi selama menjalani terapi.

\section{DAFTAR PUSTAKA}

Adewuya, A. O., Afolabi, M. O., Ola, B. A., Ogundele, O., Ajibare, A. O., Oladipo, B. F., \& Fakande, I. (2010). The Effect of Psychological Distress on Medication Adherence in Persons with HIV Infection in Nigeria. Psychosomatics, 51(1), 6873. http://doi.org/10.1016/S0033-3182(10)70661

Badan Narkotika Nasional (BNN). 2006. Kebijakan dan Strategi Nasional Bidang Pencegahan dan Pemberantasan Penyalahgunaan dan Peredaran Gelap Narkoba (P4GN). www.bnn.go.id. Diakses 30 Januari 2016

Callazos, J., Martinez, E., \& Ibarra, J. M. (2000). Sexual Hormone in HIV-Infected Patients: The Influence of Antiretroviral Therapy. International Journal of STD \& AIDS, 16, 934-7 
Elinore, F. (2007). Interaction between Buprenorphine and Atazanavir or Atazanavir/ Ritonavir. Drug Alcohol Depend. 2007 Juli 20: 17643869 (P.S.E.B.D) http//lib.bioinfo.pl/auth:Difrancesco.R

Eluwa, G. I., Badru, T., \& Akpoigbe, K. J. (2012). Adverse Drug Reactions to Antiretroviral Therapy (ARVs): Incidence, Type and Risk Factors in Nigeria. BMC Clinical Pharmacology, 12(7)

Kemenkes RI. (2012). Pedoman Nasional Tatalaksana Klinis Infeksi HIV dan Terapi Antiretroviral pada Orang Dewasa. Jakarta: Dirjen P2PLKemenkes RI

Kemenkes RI. (2014). Infodatin: Situasi dan Analisis HIV AIDS. Jakarta: Pusat Data dan Informasi Kementerian Kesehatan RI

Lerner, R., Kibler, J. L., \& Zeichner, S. B. (2013). Relationship between MindfulnessBased Stress Reduction and Immune Function in Cancer and HIV / AIDS. Cancer and Clinical Oncology, 2(1), 62-72. http://doi.org/10.5539/cco.v2n1p62

Mattick, R. P., Breen, C., Kimber, J,. Davoli, M. (2003). Methadone Maintenance Therapy Versus no Opiod Replacement Therapt for Opiod Dependence. The Cochrane Database of System Review, 2

Padila, P. (2012). Buku Ajar Keperawatan Medikal Bedah. Yogyakarta: Nuha Medika

Preston, A., \& Doverty., M. (2006). Buku Saku Metadon. (Asliati asril: Penerjemah). Jakarta: WHO dan RSKO

Robinson, F. P., Matthews, H. L., \& Witek, J. L. (2003). Psycho Endocrine Immune Response to Mindfulness-Based Stress Reduction in Individuals Infected with the Human Immunodeficiency Virus: A Quasiexperimental Study. The Journal of Alternative and Compelementary Medicine, 9, 683-694

Sharma, A., Vora, R., Modi, M., Sharma, A., \& Marfatia, Y. (2008). Brief Report Adverse Effects of Antiretroviral Treatment, 74(3). Diakses 20 Januari 2016

Sherr, S. (2007). Psychological Factors HIV/AIDS.www.blackwell-sinergy.com diakses 20 Januari 2016

SK Menkes RI. (2006). Keputusan Menteri Kesehatan Republik Indonesia nomor: 494/MENKES/SK/VII/2006. http://www.kpa.org diakses tanggal 25 Februari 2016

Smeltzer, S. C., \& Bare, B. G. (2010). Brunner \& Suddarth's Textbook of MedicalSurgical Nursing (Ed.10 Vol.3). Philadelphia: Lippincott-Raven Publisher

Strathdee, S. A., Hallett, T. B., Bobrova, N., Rhodes, T., Booth, R., Abdool, R., \& Hankins, C. A. (2010). HIV and Risk Environment for Injecting Drug Users: the Past, Present, and Future. Lancet (London, England), 376(9737), 268-284. https://doi.org/10.1016/S0140-6736(10)60743-X

Sugiharti, S., Yuniar, Y., \& Lestary, H., (2014). Gambaran Kepatuhan Orang dengan HIV AIDS (ODHA) dalam Minum Obat ARV di Kota Bandung, Provinsi Jawa Barat Tahun 2011-2012. Bandung: Teknologi, Kesehatan, \& Litbangkes, 2014)

UNAIDS (2014). The Global AIDS Response (GAP) Progress Report 2014: People Who Inject Drugs. Switzerland: Joint United Nation Programme on HIV AIDS (UNAIDS) Information Production Inc

United Nations Office on Drugs and Crime (UNODC). (2015). World Drug Report 2015. United nations Publication Sales No.E.15.XI.6

WHO. (2008). HIV/AIDS Treatment and Care for Injecting Drug Users: Clinical Protocol for the WHO european Region.WHO

WHO., UNAIDS., \& UNODC., (2005). Evidence for Action on HIV/AIDS. Policy Brief: Antiretroviral Therapy and Injecting Drug Users. WHO/HIV/2005.06 
Woodward, E. N., \& Pantalone, D. W. (2012). The Role of Social Support and Negative Affect in Medication Adherence for HIV-Infected Men Who Have Sex with Men. Journal of the Association of Nurses in AIDS Care, 23(5), 388-396. http://doi.org/10.1016/j.jana.2011.09.00

Yuniar, Y., Handayani, R. S., \& Aryastami, N. K. (2012). Faktor-Faktor Pendukung Kepatuhan Orang Dengan HIV AIDS (ODHA) dalam Minum Obat Antiretroviral di Kota Bandung dan Cimahi. Buletin Peneliti kesehatan, 41(2), 72-83 